\title{
Lead Isotopes Combined with Geochemical Baseline in Sediments: A Novel Tool to Trace Anthropogenic $\mathrm{Pb}$ Sources
}

\author{
Dongyu $\mathrm{Xu}{ }^{1,2}$ and Bo Gao ${ }^{1,2, *(D)}$ \\ 1 State Key Laboratory of Simulation and Regulation of Water Cycle in River Basin, \\ China Institute of Water Resources and Hydropower Research, Beijing 100038, China; xudy@iwhr.com \\ 2 Department of Water Environment, China Institute of Water Resources and Hydropower Research, \\ Beijing 100038, China \\ * Correspondence: gaobo@iwhr.com; Tel.: +86-10-6878-1893
}

Received: 14 January 2020; Accepted: 7 February 2020; Published: 10 February 2020

\begin{abstract}
Traditional $\mathrm{Pb}$ isotopic identification only based on total $\mathrm{Pb}$ concentration and $\mathrm{Pb}$ isotopic ratios, resulted in difficulty for tracing $\mathrm{Pb}$ sources in the complex environmental medium, especially for sediment. Herein, a novel approach combining with regional geochemical baseline (RGB) and $\mathrm{Pb}$ isotopic ratios are used to directly trace anthropogenic $\mathrm{Pb}$ sources and calculate $\mathrm{Pb}$ source appointments in sediment. In this study, total $\mathrm{Pb}$ concentrations and isotopic ratios were analyzed for a 7-m long sediment core (92 sediment samples) collected from a reservoir. RGB of $\mathrm{Pb}$ was used to calculate anthropogenic $\mathrm{Pb}$ concentrations $\left(\mathrm{R}_{\mathrm{d}}\right)$, their contributions $\left(\mathrm{C}_{\mathrm{Rd}}\right)$ and screen the sediments influenced by anthropogenic activities. Among those sediments influenced by anthropogenic activities, a positive correlation was found between ${ }^{206} \mathrm{~Pb} /{ }^{207} \mathrm{~Pb}$ ratios and $\mathrm{R}_{\mathrm{d}}$, indicating there were two anthropogenic $\mathrm{Pb}$ sources in sediment. Further source identification using ${ }^{206} \mathrm{~Pb} /{ }^{207} \mathrm{~Pb}$ and ${ }^{208} \mathrm{~Pb} /{ }^{207} \mathrm{~Pb}$ indicated that these two anthropogenic $\mathrm{Pb}$ sources originated from coal consumption and aerosol input. Finally, $\mathrm{C}_{\mathrm{Rd}}$ and $\mathrm{Pb}$ isotopic ratios were used to calculate these two $\mathrm{Pb}$ source appointments $(1.13 \%$ for coal consumption and $7.53 \%$ for aerosol input). This study demonstrated that source identification using $\mathrm{RGB}$ and $\mathrm{Pb}$ isotopes could be a novel attempt for identifying anthropogenic $\mathrm{Pb}$ sources in sediment.
\end{abstract}

Keywords: lead $(\mathrm{Pb})$; regional geochemical baseline; $\mathrm{Pb}$ isotopes; sediments; source identification

\section{Introduction}

Trace metals in aquatic environments are a source of substantial concern due to their toxicity, persistence, and biological enrichment by the food chain [1,2]. In fact, sediments are a reservoir of trace metal contaminants. Over $90 \%$ of the metals in aquatic systems occur in the sediments or suspended particles [3,4]. In the aquatic environment, various physicochemical processes (e.g., precipitation, adsorption, and chelation) lead to the deposition of trace metals in sediments [5]. On the other hand, due to the change of the physicochemical conditions (e.g., $\mathrm{pH}$, Eh, sediment resuspension, desorption, and redox reaction), sediment is also a potential source of trace metals as it has the potential to rerelease the trace metals back into the water column [6]. Therefore, sediment is the sink and source for trace metals in aquatic ecosystems. It is also an important medium for understanding the geochemical characteristics and environmental behavior of trace metals.

The effective measurement of protecting water quality is to control and reduce the anthropogenic input of pollutants. Source identification of pollutants is a key scientific issue that cannot be ignored. As a toxic metal, lead $(\mathrm{Pb})$ contamination in sediments has been reported worldwide due to the wide industrial uses and serious threat to human health, particularly when bioaccumulated in the tissues of organisms and biomagnified through the food web [7]. $\mathrm{Pb}$ in the environment is generally released by 
the natural weathering of parent rocks and anthropogenic sources (e.g., gasoline, coal combustion, mining activities, and industrial emissions) [8]. In fact, strong efforts to identify metal pollution sources entering the aquatic ecosystems have been attempted in the past several decades (e.g., principal component analysis, clustering analysis, and multivariate statistical analysis) [9-11]. These traditional methods usually require large databases and sophisticated statistics and cannot be used to accurately identify the potential origins of trace metals [12]. $\mathrm{Pb}^{\prime}$ s stable isotope is one of the most powerful isotopic fingerprinting tools to differentiate the various sources of $\mathrm{Pb}$ among complex environmental matrices [12]. Nevertheless, due to the high complexity and heterogeneity of the sediments, it was difficult to trace $\mathrm{Pb}$ sources only by establishing the relationship between the total $\mathrm{Pb}$ concentrations and their corresponding $\mathrm{Pb}$ isotopic ratios [12,13]. Based on these reasons, a new development in the application of $\mathrm{Pb}$ isotopes is needed to coordinate with other information, including the geographic information system (GIS) mapping, other elements' isotopes, and so on [14-16]. In recent years, the regional geochemical baseline (RGB) of trace metals has been recognized as a useful tool to distinguish between trace metals from anthropogenic input and natural sources $[17,18]$. In fact, the essence of the source identification of $\mathrm{Pb}$ pollution is to identify the anthropogenic $\mathrm{Pb}$ sources. Assuming that there was a direct relationship between anthropogenic input information and these corresponding $\mathrm{Pb}$ isotopic ratios, this would provide useful information to assist the identification of $\mathrm{Pb}$ sources in sediments. In this context, the major objectives of this study were to (1) establish the RGB model and calculate the amount and contribution of anthropogenic $\mathrm{Pb}$ in sediments; (2) establish the relationship between the amount of anthropogenic $\mathrm{Pb}$ and their corresponding $\mathrm{Pb}$ isotopic ratios; and (3) determine the anthropogenic $\mathrm{Pb}$ sources and their contributions by combining the RGB model and $\mathrm{Pb}$ isotopic ratios. To the best of our knowledge, our effort is a good attempt and enriches the method of $\mathrm{Pb}$ isotopic identification with the help of the geochemical approach in sediments.

\section{Materials and Methods}

\subsection{Sampling Sites}

Daheiting Reservoir (DHTR) is located in the junction between the cities of Chengde and Tangshan in Hebei province. The function of this reservoir is to carry the water from its upper reservoir (the Panjiakou reservoir) and then raise the water level to provide water for both Tianjin and Tangshan. The total capacity of DHTR is 337 million $\mathrm{m}^{3}$. A 7-m long sediment core was obtained in downstream of DHTR. The first $1 \mathrm{~m}$ of this sediment core was cut into $2 \mathrm{~cm}$ long sections, and the other sediment core was cut into $5 \mathrm{~cm}$ long sections. The sediment samples were placed in clean polyethylene bags and treated immediately upon returning to the laboratory. All samples were freeze-dried, gently crushed and ground in an agate mortar, and passed through a $0.25 \mathrm{~mm}$ nylon sieve for further analysis.

\subsection{Measurement of Trace Metals Concentrations}

All chemical treatments were performed in an ultraclean laboratory and all reagents were of a high purity grade. A strong acid digestion method $\left(\mathrm{HNO}_{3}+\mathrm{H}_{2} \mathrm{O}_{2}+\mathrm{HF}\right)$ was used to digest the samples in solution [19]. The digested solutions were measured using Inductively Coupled Plasma-mass Spectrometry (ICP-MS, Perkin Elmer Elan DRC-e) for Pb and Li concentrations. Quality control of trace metals was tested by certified reference materials of the stream sediment (GSD-1a), which were purchased from the Chinese Institute of Geophysical and Geochemical Exploration. Analytical results agreed well with the certified values (the recovery rates of $\mathrm{Pb}$ and $\mathrm{Li}$ were $102.35 \%$ and $96.31 \%$, respectively).

\subsection{Analysis of Pb Isotopic Composition}

Isotopes of $\mathrm{Pb}$ were separated for analyses using ion-exchange microcolumns of Dowex-I anion resin (200-400 mesh) and $\mathrm{HBr}$ and $\mathrm{HCl}$ as eluents [20]. Measurements of $\mathrm{Pb}$ isotopic composition were carried out using an ICP-MS (Perkin Elmer Elan DRC-e). The average measured values of the standard 
NIST SRM-981 were ${ }^{206} \mathrm{~Pb} / 207 \mathrm{~Pb}=1.094 \pm 0.001$ and ${ }^{207} \mathrm{~Pb} /{ }^{208} \mathrm{~Pb}=0.422 \pm 0.002(\mathrm{~N}=20)$, respectively, which were in close agreement with the certified standard values (1.093 and 0.422 , respectively). The relative standard deviations (RSD) of $\mathrm{Pb}$ isotopic ratios were generally $<0.5 \%(\mathrm{~N}=20)$.

\subsection{Statistical Analysis}

Statistical analyses were carried out using the SPSS 17.0 software and the Sigmaplot 10.0 for Windows. Pearson's correlation was used to analyze the significance level in this study.

\section{Results and Discussion}

\subsection{Tracing Pb Sources Using the Traditional Pb Isotopic Approach}

Isotopic identification has been successfully applied for tracing $\mathrm{Pb}$ sources in different environmental matrices. In terms of $\mathrm{Pb}$, the traditional method investigated the relationship between ${ }^{206} \mathrm{~Pb} /{ }^{207} \mathrm{~Pb}$ ratios and the reciprocal of $\mathrm{Pb}$ concentrations/ $\mathrm{Pb}$ concentrations to establish a linear equation to identify $\mathrm{Pb}$ sources [21]. The simple binary model was commonly used to calculate the approximate contributions of the two end-members (i.e., background $\mathrm{Pb}$ vs. anthropogenic $\mathrm{Pb}$ input) [22]. In this study, there was a weak correlation between the ${ }^{206} \mathrm{~Pb} /{ }^{207} \mathrm{~Pb}$ ratios and the reciprocal of $\mathrm{Pb}$ concentrations in sediments $\left(\mathrm{R}^{2}=0.2408\right)$ (Figure 1$)$, implying that more than two possible sources of $\mathrm{Pb}$ in this sediment profile [23]. In this condition, the $\mathrm{Pb}$ sources cannot be identified easily because sediments are heterogeneous and it is difficult to ascertain the $\mathrm{Pb}$ sources in sediment core [13]. Previous study suggests that other identification methods are needed to help in tracing $\mathrm{Pb}$ sources (e.g., GIS or isotopic information of other elements) [12]. However, these methods need extensive calculations, experiments, and complicated isotopic instruments. Therefore, it is necessary to find assistant methods to solve the problem during the process of tracing $\mathrm{Pb}$ sources in aquatic environments.

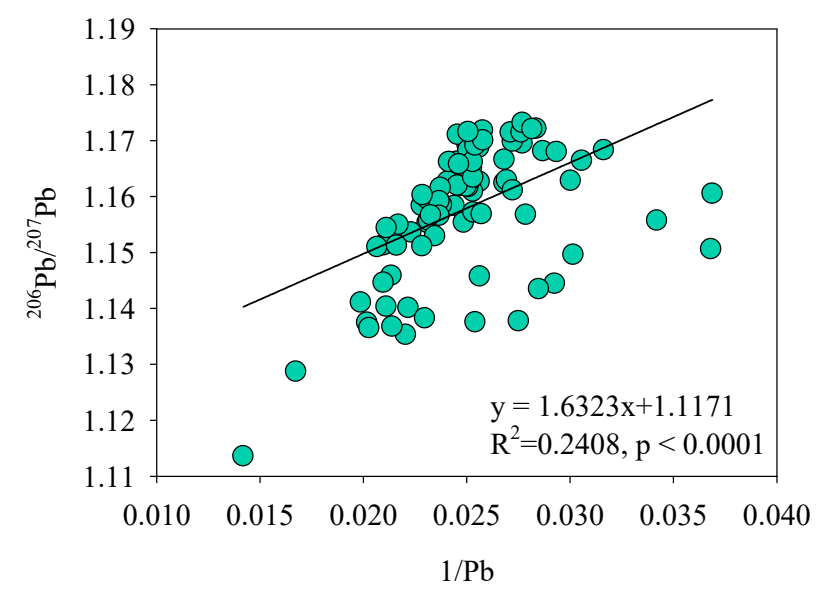

Figure 1. Relationships between $\mathrm{Pb}$ contents and ${ }^{206} \mathrm{~Pb} /{ }^{207} \mathrm{~Pb}$ ratios before screening by regional geochemical baseline (RGB).

\subsection{Establishment of $\mathrm{Pb}$ Geochemical Baseline in Sediment Core}

The RGB model was regarded as an effective tool to differentiate between anthropogenic and natural sources in soils or sediments $[17,18,24]$. In this study, the RGB model was used to distinguish between anthropogenic and natural $\mathrm{Pb}$ sources in $7-\mathrm{m}$ long sediment core. The $\mathrm{RGB}$ of $\mathrm{Pb}(\mathrm{RGB}-\mathrm{Pb})$ in the sediment core and the corresponding RGB-Pb model were calculated by the normalization method and are presented in Figure 2 [25]. 


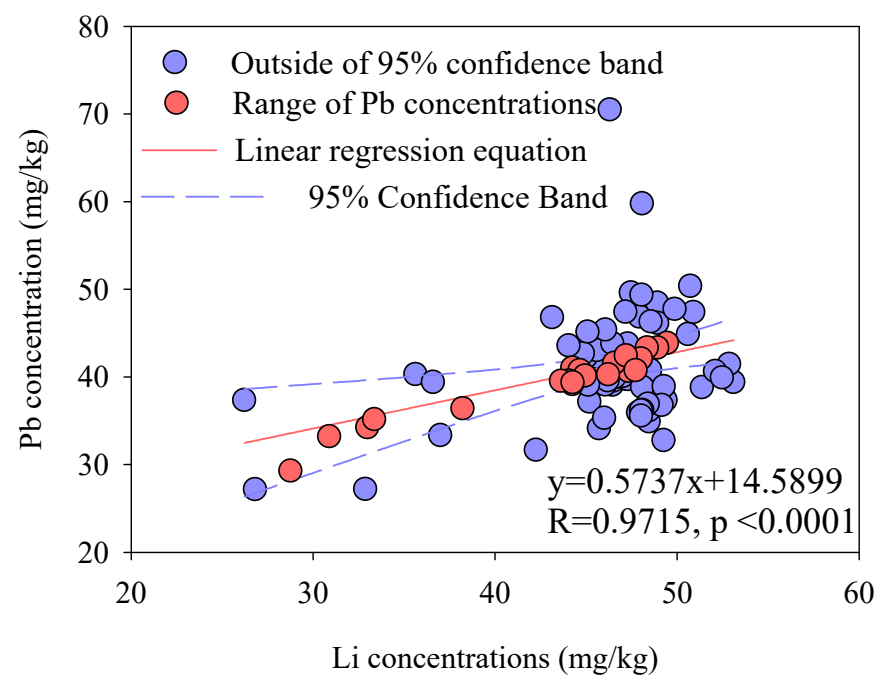

Figure 2. The process of establishing the RBG-Pb model.

Lithium ( $\mathrm{Li}$ ) was chosen as the inert element to calculate the RGB-Pb in this study because Li could avoid the influence of the anthropogenic inputs and the interference of particle size in sediments $[17,25]$. Firstly, the linear regression equation between $\mathrm{Pb}$ and $\mathrm{Li}$ should be established as followed:

$$
\mathrm{C}_{\mathrm{Pb}}=\mathrm{a} \times \mathrm{C}_{\mathrm{Li}}+\mathrm{b}
$$

where $\mathrm{C}_{\mathrm{Pb}}$ and $\mathrm{C}_{\mathrm{Li}}$ are the concentrations of $\mathrm{Pb}$ and $\mathrm{Li}$ in the sediment core, respectively, $\mathrm{mg} / \mathrm{kg}$; a and $\mathrm{b}$ are the regression constants. In the $\mathrm{x}-\mathrm{y}$ scatterplot described by Equation (1), according to the method reported previously [25], the data outside the $95 \%$ confidence limit were characterized as anthropogenic sources and were removed. The remaining data inside the $95 \%$ confidence limit were characterized as natural sources. These remaining data were re-established as a new regression equation, then obtained new regression constants ( $c$ and $d$ ) were established as the RGB-Pb model following the equation:

$$
\mathrm{B}_{\mathrm{m}}=\mathrm{c} \times \overline{\mathrm{C}_{L i}}+\mathrm{d}
$$

where $B_{\mathrm{m}}$ is the $\mathrm{RGB}-\mathrm{Pb}, \mathrm{mg} / \mathrm{kg} ; \overline{C_{L i}}$ is the average concentration of Li samples inside the $95 \%$ confidence limit, $\mathrm{mg} / \mathrm{kg}$; $\mathrm{c}$ and $\mathrm{d}$ are the new regression constants. Using the average concentration of remaining data for $\mathrm{Li}$, the naturally sourced $\mathrm{Pb}$ concentration was obtained. This $\mathrm{Pb}$ value was defined as the value of RGB-Pb. In terms of above Equation (2), the $B_{m}$ (RGB-Pb) was $39.63 \mathrm{mg} / \mathrm{kg}$, which was approximate to the average of $\mathrm{Pb}$ in sediment core $(40.77 \mathrm{mg} / \mathrm{kg})$, implying that there was only a slight accumulation of $\mathrm{Pb}$ in the sediment core.

\subsection{Distinguish Anthropogenic and Natural Pb Sources Using RGB-Pb}

According to the RGB-Pb model, the RGB-Pb in each sample $\left(\mathrm{B}_{\mathrm{mi}}, \mathrm{i}=92\right)$ could be calculated [18]. Then, in terms of these $B_{m i}$ values, the anthropogenic $\mathrm{Pb}$ concentrations $\left(R_{d}\right)$ were the values of the real $\mathrm{Pb}$ concentrations $\left(\mathrm{D}_{\mathrm{mi}}\right)$ minus their corresponding $\mathrm{B}_{\mathrm{mi}}$ in each sample (Equation (3)) (Figure $3 \mathrm{~A}, \mathrm{~B}$ ). Using the $R_{d}$ values could differentiate between natural sources and anthropogenic sources $\left(R_{d}>0\right.$ indicating anthropogenic input; $R_{d} \leq 0$ indicating natural input). Furthermore, the percentage of anthropogenic contribution $\left(C_{R d}\right)$ in the sediment core could be calculated by Equation (4).

$$
\begin{gathered}
R_{d}=D_{m i}-B_{m i}, i=1 \ldots 92 \\
C_{R d}(\%)=100 \times R_{d} / B_{m i}
\end{gathered}
$$



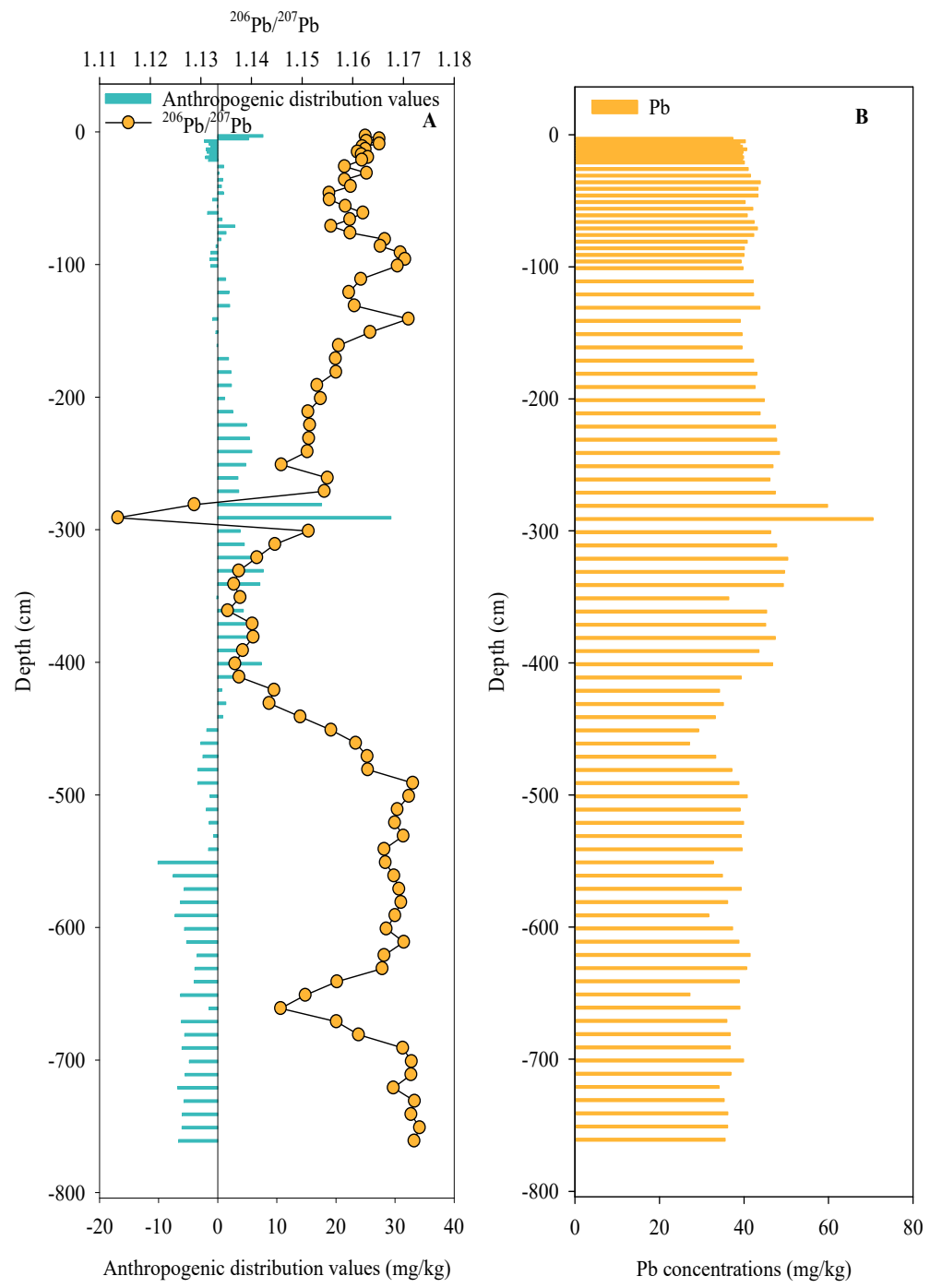

Figure 3. $\mathrm{Pb}$ concentrations, distribution characteristics of anthropogenic distribution values, and ${ }^{206} \mathrm{~Pb} /{ }^{207} \mathrm{~Pb}$ in sediment profile ((A) presents the distribution values of $\mathrm{R}_{\mathrm{d}}$ and ${ }^{206} \mathrm{~Pb} /{ }^{207} \mathrm{~Pb}$ in sediment profile; (B) presents the distribution of $\mathrm{Pb}$ concentrations in sediment profile).

According to Equation (4), the average of the $C_{R d}$ (anthropogenic contribution) value was $8.66 \%$, which also suggested that the $\mathrm{Pb}$ slightly accumulated in the sediment core and mainly originated from a natural source. In addition, according to Figure $3 A$, most $R_{d}$ exhibited positive values from the depth of $-2 \mathrm{~m}$ to $-4 \mathrm{~m}$ in the sediment core, indicating that anthropogenic input was present in these samples. To determine the sources of the anthropogenic $\mathrm{Pb}$ input in these samples, the two parameters $\left(\mathrm{R}_{\mathrm{d}}\right.$ and the $\mathrm{Pb}$ isotope) in these samples were used for further analysis of the $\mathrm{Pb}$ sources. Interestingly, there was an opposite trend between the $R_{d}$ and the distribution characteristics of the ${ }^{206} \mathrm{~Pb} /{ }^{207} \mathrm{~Pb}$ ratios in these positive samples (Figure $3 \mathrm{~A}$ ). Moreover, the correlation analysis showed that a negative correlation truly existed between the $R_{d}\left(R_{d}>0\right)$ and ${ }^{206} \mathrm{~Pb} /{ }^{207} \mathrm{~Pb}$ ratios $\left(\mathrm{R}^{2}=0.7865\right.$, $p<0.0001$ ) (Figure 4), indicating that the binary model can identify the Pb sources in these selected anthropogenic sediments after screening by RGB model. Hence, our results demonstrated that $R_{d}$ and $\mathrm{Pb}$ isotopic ratios were effective parameters for tracing anthropogenic $\mathrm{Pb}$ in sediments compared with the traditional isotopic identification method that used the reciprocal of $\mathrm{Pb}$ concentrations $/ \mathrm{Pb}$ concentrations and $\mathrm{Pb}$ isotopic ratios. 


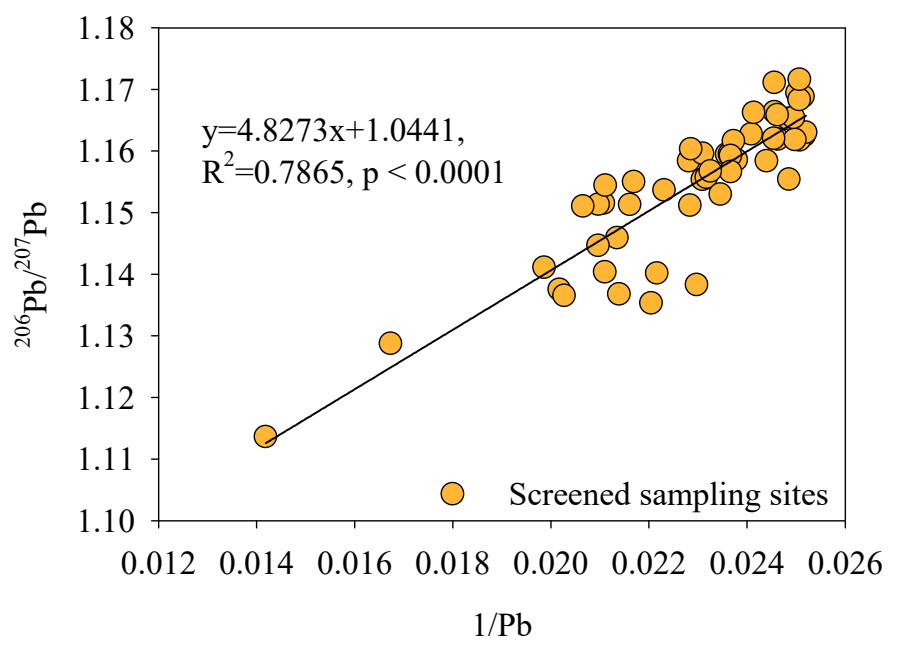

Figure 4. Relationships between $\mathrm{Pb}$ contents and ${ }^{206} \mathrm{~Pb} /{ }^{207} \mathrm{~Pb}$ ratios after screening by RGB.

\subsection{Source Identification of Anthropogenic Pb in Sediments}

To further identify the sources of anthropogenic $\mathrm{Pb}$ deposited in the sediments, the measured isotope ratios were compared to those of source-specific materials. The $\mathrm{Pb}$ isotopic compositions of those source-specific materials are listed in Table 1 . Overall, the average value of the ${ }^{206} \mathrm{~Pb} /{ }^{207} \mathrm{~Pb}$ ratios and ${ }^{208} \mathrm{~Pb} /{ }^{207} \mathrm{~Pb}$ for different anthropogenic $\mathrm{Pb}$ samples were 1.150 and 2.458 , respectively. The $\mathrm{Pb}$ isotopic ratios in anthropogenic $\mathrm{Pb}$ samples screened by RGB model located nearly to the samples of coal and aerosol, indicating anthropogenic $\mathrm{Pb}$ should be homologous with the values of coal and aerosol (Figure 4). This result meant that coal consumption and aerosol deposition might be the sources of the anthropogenic $\mathrm{Pb}$ in sediments. Additionally, the linear correlation of the $\mathrm{Pb}$ isotope ratios $\left({ }^{206} \mathrm{~Pb} /{ }^{207} \mathrm{~Pb}\right.$ vs. $\left.{ }^{208} \mathrm{~Pb} /{ }^{207} \mathrm{~Pb}\right)$ in these samples was significant $\left(\mathrm{R}^{2}=0.8567\right)$ (Figure 5$)$, also suggesting that the $\mathrm{Pb}$ in the sediments fit a binary mixing model. This model indicated that sediments could receive $\mathrm{Pb}$ from two sources (Figure 5). Consequently, the anthropogenic $\mathrm{Pb}$ originated from the coal and the aerosol in this study. Moreover, this result further suggests that the atmospheric deposition of coal combustion dust might be speculated to be the major transportation pathway for anthropogenic $\mathrm{Pb}$ input to DHTR sediments.

Table 1. Values of $\mathrm{Pb}$ isotope ratio of different sources.

\begin{tabular}{cccc}
\hline & ${ }^{\mathbf{2 0 6}} \mathbf{P b} /{ }^{\mathbf{2 0 7}} \mathbf{P b}$ & ${ }^{208} \mathbf{P b} /{ }^{\mathbf{2 0 7}} \mathbf{P b}$ & References \\
\hline Anthropogenic Pb in sediments & 1.150 & 2.458 & This study \\
Aerosol in Beijing & 1.148 & 2.444 & {$[26]$} \\
Coal in Shanghai & 1.163 & 2.462 & {$[27]$} \\
Coal in Shanghai & 1.163 & 2.456 & {$[27]$} \\
Cement & 1.163 & 2.447 & {$[27]$} \\
Coal in Beijing & 1.172 & 2.460 & {$[28]$} \\
Northern China coal & 1.178 & 2.503 & {$[30]$} \\
Vehicle exhaust (leaded) & 1.110 & 2.434 & {$[30]$} \\
Vehicle exhaust(unleaded) & 1.147 & 2.435 & {$[31]$} \\
Ore (Hebei) & 1.072 & 2.452 & {$[31]$} \\
Ore (Hebei) & 1.090 & 2.438 & {$[32]$} \\
Natural source & 1.184 & 2.482 & {$[32]$} \\
& 1.183 & 2.468 & {$[33]$} \\
& 1.195 & 2.482 & {$[34]$} \\
& 1.196 & 2.489 & {$[35]$} \\
\hline
\end{tabular}




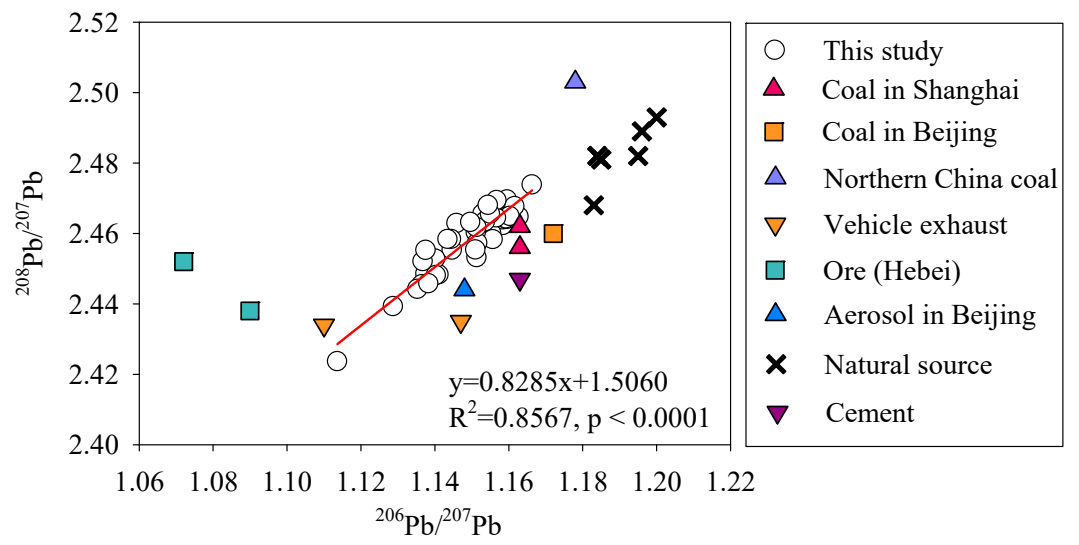

Figure 5. Isotopic composition $\left({ }^{208} \mathrm{~Pb} /{ }^{207} \mathrm{~Pb}\right.$ versus $\left.{ }^{206} \mathrm{~Pb} /{ }^{207} \mathrm{~Pb}\right)$ in sediment.

To quantify the $\mathrm{Pb}$ contributions of coal consumption and aerosol input (anthropogenic sources) in sediments, the following binary mixing model was adopted [36]:

$$
\begin{gathered}
R_{\text {anthropogenic }}=R_{\text {coal }} X_{\text {coal }}+R_{\text {aerosol }} X_{\text {aerosol }} \\
X_{\text {coal }}+X_{\text {aerosol }}=1
\end{gathered}
$$

where $R_{\text {anthropogenic }}$ is the average ${ }^{206} \mathrm{~Pb} /{ }^{207} \mathrm{~Pb}$ ratio of the anthropogenic $\mathrm{Pb}$ calculated from the screened samples by RGB model with a value of 1.150 . The $R_{\text {coal }}$ and $R_{\text {aerosol }}$ referred to the previous data of the ${ }^{206} \mathrm{~Pb} /{ }^{207} \mathrm{~Pb}$ ratios (1.163 for $R_{\text {coal }}$ and 1.148 for $\left.R_{\text {aerosol }}\right)$ [27,28]. According to Equations (5) and (6), the contributions of all anthropogenic $\mathrm{Pb}$ sources were calculated. Because the anthropogenic contribution of $\mathrm{Pb}$ was $8.66 \%$, the results reveal that the anthropogenic source contributions were $1.13 \%$ for coal consumption and $7.53 \%$ for aerosol input, respectively. These anthropogenic percentage values also demonstrated that the atmospheric deposition of coal combustion dust was the main transportation pathway of $\mathrm{Pb}$ in the study area. The result also correlated with a high incidence of fog and haze in North China. A previous study also observed that $\mathrm{Pb}$ was the most abundant element, independent of the particulate matter (PM) pollution levels during the wintertime in Beijing [37]. With the help of the RGB-Pb model, this study provided a novel approach to accurately quantify the contributions of multiple anthropogenic $\mathrm{Pb}$ sources using $\mathrm{Pb}$ isotopic ratios in sediments.

\section{Conclusions}

In summary, considering the essence of the identification of sources, the amount of anthropogenic $\mathrm{Pb}\left(\mathrm{R}_{\mathrm{d}}\right)$ was calculated by the RGB model, and a relationship was established between $\mathrm{R}_{\mathrm{d}}$ and $\mathrm{Pb}$ isotopic ratios. This method has broken through the traditional isotopic identification method using the correlation analysis between $\mathrm{Pb}$ concentrations/the reciprocal of $\mathrm{Pb}$ concentrations and $\mathrm{Pb}$ isotopic ratios. In addition, the combination of the anthropogenic $\mathrm{Pb}$ contribution by the RGB model with $\mathrm{Pb}$ isotopic ratios could accurately identify the different $\mathrm{Pb}$ sources in sediments. Moreover, compared with the traditional method, there were two advantages, as follows: (1) the novel approach directly identified the anthropogenic sources, which made it possible to identify the source of complex sediments. (2) This method also simplified the process of $\mathrm{Pb}$ source identification and reduced the workload of source identification. This combination approach will make it possible to trace pollution sources of other elements in the future.

Author Contributions: B.G. designed the experiments; D.X. and B.G. performed the experiment and wrote the paper; B.G. and D.X. analyzed the data and edited the paper. All authors have read and agree to the published version of the manuscript.

Funding: This research was jointly supported by the Research \& Development Support Program of China Institute of Water Resources and Hydropower Research (WE0145B072019, WE0145B662017). 
Conflicts of Interest: The authors declare no conflict of interest.

\section{References}

1. Gonzalez, Z.I.; Krachler, M.; Cheburkin, A.K.; Shotyk, W. Spatial distribution of natural enrichments of arsenic, selenium, and uranium in a minerotrophic peatland, Gola di Lago, Canton Ticino. Switzerland. Environ. Sci. Technol. 2006, 40, 6568-6574. [CrossRef] [PubMed]

2. Deniseger, J.; Erickson, J.; Austin, A.; Roch, M.; Clark, M.J.R. The effects of decreasing heavy metal concentrations on the biota of Buttle Lake. Water Res. 1990, 24, 403-416. [CrossRef]

3. Zahra, A.; Hashmi, M.Z.; Malik, R.N.; Ahmed, Z. Enrichment and geo-accumulation of heavy metals and risk assessment of sediments of the Kurang Nallah-feeding tributary of the Rawal Lake Reservoir, Pakistan. Sci. Total Environ. 2013, 470, 925-933. [CrossRef] [PubMed]

4. Zheng, N.; Wang, Q.; Liang, Z.; Zheng, D. Characterization of heavy metal concentrations in the sediments of three freshwater rivers in Huludao City, Northeast China. Environ. Pollut. 2008, 154, 135-142. [CrossRef]

5. Tang, Q.; Bao, Y.H.; He, X.B.; Zhou, H.D.; Cao, Z.J.; Gao, P.; Zhong, R.H.; Hu, Y.H.; Zhang, X.B. Sedimentation and associated trace metal enrichment in the riparian zone of the Three Gorges Reservoir, China. Sci. Total Environ. 2014, 479, 258-266. [CrossRef]

6. Bing, H.J.; Wu, Y.H.; Zhou, J.; Sun, H.Y.; Wang, X.X.; Zhu, H. Spatial variation of heavy metal contamination in the riparian sediments after two-year flow regulation in the Three Gorges Reservoir, China. Sci. Total Environ. 2019, 649, 1004-1016. [CrossRef] [PubMed]

7. Harada, M. Minamata disease: Methylmercury poisoning in Japan caused by environmental pollution. Crit. Rev. Toxicol. 1995, 25,1-24. [CrossRef]

8. Gao, L.; Li, S.H.; Wang, Z.W.; Liang, Z.B.; Chen, J.Y.; Liang, B. Contamination, potential mobility, and origins of lead in sediment cores from the Shima River, south China. Environ. Pollut. 2018, 242, 1128-1136. [CrossRef]

9. Facchinelli, A.; Sacchi, E.; Mallen, L. Multivariate statistical and GIS-based approach to identify heavy metals sources in soils. Environ. Pollut. 2001, 114, 313-324. [CrossRef]

10. Qishlaqi, A.; Moore, F. Statistical analysis of accumulation and sources of heavy metals occurrence in agricultural soils of Khoshk River banks, Shiraz, Iran. American-Eurasian J. Agric. Environ. Sci. 2007, 2, 565-573.

11. Zhao, H.; Li, X. Risk assessment of metals in road-deposited sediment along an urban-rural gradient. Environ. Pollut. 2013, 174, 297-304. [CrossRef] [PubMed]

12. Cheng, H.F.; Hu, Y.N. Lead (Pb) isotopic fingerprinting and its applications in lead pollution studies in China: A review. Environ. Pollut. 2010, 158, 1134-1146. [CrossRef] [PubMed]

13. Pedersen, L.L.; Smets, B.F.; Dechesne, A. Measuring biogeochemical heterogeneity at the micro scale in soils and sediments. Soil Biol. Biochem. 2015, 90, 122-138. [CrossRef]

14. Caravanos, J.; Weiss, A.L.; Jaeger, R.J. An exterior and interior leaded dust deposition survey in New York City: Results of a 2-year study. Environ. Res. 2006, 100, 159-164. [CrossRef] [PubMed]

15. Cloquet, C.; Carignan, J.; Libourel, G.; Stercheman, T.; Perdrix, E. Tracing Source Pollution in Soils Using Cadmium and Lead Isotopes. Environ. Sci. Technol. 2006, 40, 2525-2530. [CrossRef]

16. Duzgoren-Aydin, N.S.; Weiss, A.L. Use and abuse of Pb-isotope fingerprinting technique and GIS mapping data to assess lead in environmental studies. Environ. Geochem. Health 2008, 30, 577-588. [CrossRef]

17. Gao, L.; Gao, B.; Xu, D.Y.; Peng, W.Q.; Lu, J. Multiple assessments of trace metals in sediments and their response to the water level fluctuation in the Three Gorges Reservoir, China. Sci. Total Environ. 2019, 648, 197-205. [CrossRef]

18. Xu, D.Y.; Gao, B.; Peng, W.Q.; Lu, J.; Gao, L. Thallium pollution in sediments response to consecutive water seasons in Three Gorges Reservoir using geochemical baseline concentrations. J. Hydrol. 2018, 564, 740-747. [CrossRef]

19. Gao, B.; Zhou, H.D.; Yu, Y.; Wang, Y.C. Occurrence, distribution, and risk assessment of the metals in sediments and fish from the largest reservoir in China. RSC Adv. 2015, 5, 60322-60330. [CrossRef]

20. Zhu, B.; Zhang, J.; Tu, X.; Chang, X.; Fan, C.; Liu, Y.; Liu, J. Pb, Sr, and Nd isotopic features in organic matter from China and their implications for petroleum generation and migration. Geochim. Cosmochim. Acta 2001, $65,2555-2570$. 
21. Han, L.F.; Gao, B.; Wei, X.; Gao, L.; Xu, D.Y.; Sun, K. The characteristic of Pb isotopic compositions in different chemical fractions in sediments from Three Gorges Reservoir, China. Environ. Pollut. 2015, 206, 627-635. [CrossRef] [PubMed]

22. Monna, F.; Lancelot, J.; Croudace, I.W.; Cundy, A.B.; Lewis, J.T. Lead isotopic composition of airborne material from France and the Southern U.K. implications for $\mathrm{Pb}$ pollution sources in urban areas. Environ. Sci. Technol. 1997, 31, 2277-2286. [CrossRef]

23. Widory, D.; Liu, X.D.; Dong, S.P. Isotopes as tracers of sources of lead and strontium in aerosols (TSP \& PM2.5) in Beijing. Atmos. Environ. 2010, 44, 3679-3687.

24. Tian, K.; Huang, B.; Xing, Z.; Hu, W.Y. Geochemical baseline establishment and ecological risk evaluation of heavy metals in greenhouse soils from Dongtai, China. Ecol. Indic. 2017, 72, 510-520. [CrossRef]

25. Teng, Y.G.; Ni, S.J. Theory and Practice of Geochemical Baseline; Beijing Chemical Industry Press: Beijing, China, 2007; pp. 87-96.

26. Mukai, H.; Tanaka, A.; Fujii, T.; Zeng, Y.Q.; Hong, Y.T.; Tang, J.; Guo, S.; Xue, H.S.; Sun, Z.L.; Zhou, J.T.; et al. Regional Characteristics of Sulfur and Lead Isotope Ratios in the Atmosphere at Several Chinese Urban Sites. Environ. Sci. Technol. 2001, 35, 1064-1071. [CrossRef]

27. Tan, M.G.; Zhang, G.L.; Li, X.L.; Zhang, Y.X.; Yue, W.S.; Chen, J.M.; Wang, Y.S.; Li, A.G.; Li, Y.; Zhang, Y.M.; et al. Comprehensive Study of Lead Pollution in Shanghai by Multiple Techniques. Anal. Chem. 2006, 78, 8044-8050. [CrossRef] [PubMed]

28. Liu, Q.; Liu, Y.; Yin, J.; Zhang, M.; Zhang, T. Chemical characteristics and source apportionment of PM10 during Asian dust storm and non-dust storm days in Beijing. Atmos. Environ. 2014, 91, 85-94. [CrossRef]

29. Zheng, N.; Liu, J.; Wang, Q.; Liang, Z. Health risk assessment of heavy metal exposure to street dust in the zinc smelting district, Northeast of China. Sci. Total Environ. 2010, 408, 726-733. [CrossRef]

30. Chen, J.; Tan, M.; Li, Y.; Zhang, Y.; Lu, W.; Tong, Y.; Zhang, G.; Li, Y. A lead isotope record of Shanghai atmospheric lead emissions in total suspended particles during the period of phasing out of leaded gasoline. Atmos. Environ. 2005, 39, 1245-1253. [CrossRef]

31. Zhu, B. The mapping of geochemical provinces in China based on Pb isotopes. J. Geochem. Explor. 1995, 55, 171-181. [CrossRef]

32. Zhu, B.Q.; Chang, X.Y.; Qiu, H.N.; Sun, D.Z. Characteristics of Proterozoic basements on the geochemical steep zones in the continent of China and their implications for setting of super large deposits. Sci. China 1998, 41 (Suppl. I), 54-64.

33. Zhu, L.; Guo, L.; Gao, Z.; Yin, G.; Lee, B.; Wang, F.; Xu, J. Source and distribution of lead in the surface sediments from the South China Sea as derived from Pb isotopes. Mar. Pollut. Bull. 2010, 60, 2144-2153. [CrossRef] [PubMed]

34. Millot, R.; Allègre, C.J.; Gaillardet, J.; Roy, S. Lead isotopic systematics of major river sediments: A new estimate of the $\mathrm{Pb}$ isotopic composition of the Upper Continental Crust. Chem. Geol. 2004, 203, 75-90. [CrossRef]

35. Lee, C.S.L.; Li, X.D.; Zhang, G.; Li, J.; Ding, A.J.; Wang, T. Heavy metals and Pb isotopic composition of aerosols in urban and suburban areas of Hong Kong and Guangzhou, South China-Evidence of the long-range transport of air contaminants. Atmos. Environ. 2007, 41, 432-447. [CrossRef]

36. Komárek, M.; Ettler, V.; Chrastný, V.; Mihaljevič, M. Lead isotopes in environmental sciences: A review. Environ. Int. 2008, 34, 562-577. [CrossRef]

37. Huang, R.J.; Cheng, R.; Jing, M.; Yang, L.; Li, Y.J.; Chen, Q.; Chen, Y.; Yan, J.; Lin, C.S.; Wu, Y.F. Source-specific health risk analysis on particulate trace elements: Coal combustion and traffic emission as major contributors in wintertime Beijing. Environ. Sci. Technol. 2018, 52, 10967-10974. [CrossRef]

(C) 2020 by the authors. Licensee MDPI, Basel, Switzerland. This article is an open access article distributed under the terms and conditions of the Creative Commons Attribution (CC BY) license (http://creativecommons.org/licenses/by/4.0/). 